\title{
Village Voices: Public Hearings as Ethnographic Data in Border Village Communities
}

Received: November 24, 2020 • Accepted: December 14, 2020

Csaba Mészáros

Institute of Ethnology, Research Centre for the Humanities, Budapest

\begin{abstract}
The aim of the present study is to demonstrate the usefulness of, and the lessons that can be learned from, a type of source that has been insufficiently analyzed and used to date - that is, the minutes of local councils, and of public hearings in particular. Data from 29 sets of minutes from four neighboring small settlements in the Hungarian-Slovenian border region (Apátistvánfalva, Kétvölgy, Kondorfa, and Orfalu) suggest that the use and inclusion in research of the text corpus that comprises the large available quantities of such sources can effectively supplement, although not replace, ethnographic fieldwork based on participant observation. At the same time, the examination of this text corpus, along with other internal sources belonging to the local public sphere, makes it possible to construct an image of the internal workings of a settlement and the dynamics of its power relations that would not otherwise be accessible for study.
\end{abstract}

Keywords: public hearings, narrative knowledge, power relations, local government, environmental protection

\section{INTRODUCTION}

The aim of this article is to examine a group of sources that have so far been used only marginally in Hungarian ethnographic research. I argue, that the analysis of this corpus of texts, which comprises the minutes of local government meetings, can make an effective contribution to research that aimes primarily at examining internal communication within a village community, the local public sphere, and power relations. From an ethnographic point of view, the most valuable of these minutes are those that record what takes place at the mandatory annual public hearings. According to the Municipality Law, all settlements with an independent local council are obliged to hold at least one public hearing each year. The minutes of the public hearings are public, and in many cases they are available online.

In the present study, I argue that these documents, in the appropriate social context, provide an insight into the internal relationships and the agoras of communication in small local communities in Hungary. Local governments and local councils cannot 
and should not be perceived exclusively as political entities, but as the institutional embodiment of the internal regulatory system of a community and its balance of power.

Besides shedding light on the functioning of the local society, these minutes, in some cases, also provide a record of the workings of the local community's communication system. Although the minutes cannot be regarded as precise and reliable texts from an ethnographic point of view, the very fact that the local government edits the texts and decides which voices are recorded, and how, means (as I argue below) that they provide a valuable source regarding which areas of local community speech can be considered legitimate and acceptable, and which not.

In my perspective, public hearings belong within the historical institutional framework that ranges from village laws and customary law through the Socialist council meetings and village meetings to the legally decreed judicial environment of the local government. However, like the above-mentioned sources, the question of how to use and interpret the sources that make up this substantial text corpus remains largely unexplored from a methodological point of view. Since this text corpus has not received sufficient attention from an ethnographic point of view, I will also endeavor to propose three relevant contexts for the analysis of public hearings from three perspectives before introducing the texts that I examined.

At the beginning of the study, I present the internal regulatory systems and records that, prior to the current local government system, produced documents that are comparable, in terms of their content and function, to the minutes of the public hearings. I argue that the institution of the public hearing is not entirely without precedent in Hungarian villages. Such precedents are worth considering not only from the perspective of public law but also from an ethnographic point of view.

I then briefly describe the function and organizational framework of the public hearing as a constitutional institution in Hungary. In this chapter, I aim to highlight the possibilities offered by the regulation of public hearings for local governments and residents to discuss the internal affairs of their settlements. At the same time, I point out that a public institution can achieve its objective only if it is suitably embedded in the fabric of local society.

Finally, I point out some opportunities for the interpretation of the minutes of public hearings based on discourse theory, in particular intending to analyze the available text corpus not only as texts but at the same time also as utterances. This is particularly important because the specific forum of the public hearing encourages residents to ask questions and express conflicting opinions - to varying degrees depending on the village and the local government.

After introducing these three aspects, I present examples from four villages in the Hungarian-Slovenian border area (Orfalu, Kétvölgy, Kondorfa, and Apaistvafalva), illustrating how public hearings are organized, conducted, and recorded. In the course of my investigation, I analyzed 29 sets of minutes, comprising a total of 321 pages, taking all three aspects into account to demonstrate the usefulness of this new source. 


\section{THE VILLAGE PUBLIC SPHERE}

The examination of the public sphere of a local community (typically a village) and of the structure of local communication has long been a key topic in Hungarian ethnographic research. Such research has analyzed the structure and function of the local public sphere drawing on three (independent) methodologies.

1. The first of these focused on language and speaking - that is, on the texts and speech events that fill out the frameworks of the village public sphere. The speech acts and texts create a complex and multilayered field of communication. When researchers approach the local public sphere from the direction of texts and speech acts, they begin with the texts and move in the direction of practices and behavior. ${ }^{1}$ Although languageoriented ethnography has a strong tradition in Hungary, dating back to the late $19^{\text {th }}$ century (GuLYA 1970), the question of how texts and utterances shed light on the structure of the local public sphere emerged only occasionally right up until the 1970s.

In this respect, the work of Mihály Hoppál can be regarded as pioneering study. Using the example of the village of Visonta, based on fieldwork data the author demonstrated that residents used an internal communication system relying on a fairly uniform register of utterances adapted to local framinf of various speech acts (HoppáL 1970). Despite being the first work to juxtapose the examination of village texts, communication occasions, social control, and decision-making processes, the volume merely raises questions and highlights opportunities for research rather than providing systematic answers.

Works of linguistic anthropology, or rather works that take into consideration the methodology of linguistic anthropology, have been published in Hungarian ethnographic literature for nearly two decades (VEREBÉLYI 2005). These works seek to establish a fieldwork centered methodology in Hungarian ethnographic research, which examines texts primarily from the point of view of speech acts and practices. Gábor Vargyas's fieldwork in Lészped (VARGYas 2006) is a good example of this. At the same time a practice- and utterance-oriented approach can be observed among Hungarian linguists, embodied in the investigation of everyday language use and individual speech acts (BATÁR 2007). The first summary in Hungarian of the various linguistic anthropological works and methods was produced by Géza Balázs and Szilvia Takács (BALÁzs - TAKÁCs 2009).

Vilmos Keszeg, who, as a folklorist, turned his attention to the fora of speech acts and communication in village communities, as well as to speech and communicative situations that emerge in the local public sphere, has enriched the Hungarian literature with even more valuable works on ethnography of speeking. Storytelling, as the author points out based on his fieldwork experience, consists not only of the transmission of narrative content but also the experiencing of the complex storytelling situation (KeSZEG 2011). Philological analysis enlightens only one aspect of the storytelling situation: the whole picture includes the social context and the description of the local storytelling framework (Keszeg 2012). Case studies in which the framing of the transmitted information and communicative situation coincides with the medial change of the text are particularly instructive (KeSZEG 2002).

\footnotetext{
${ }^{1}$ An excellent early example of this is the study by Ákos Szendrey (SzENDREY 1937).
} 
2. Another direction of research has also played a significant role in the examination of the local public sphere. These works have focused on habits, behavioral norms, and the community's internal control system - in other words, on the actions (thus not primarily on the texts!) that occur, and may occur, in the local public sphere. Typically through the study of behavioral anomalies and regulatory procedures (KoTICs 1993), this direction of research has pointed to the fact that the local public sphere is permeated by norms that do not always take a verbalized form (see also Kotics 2001). It is not only the sporadic data that appear in numerous sociographies (MÁRKUs 1979), peasant stories, and village monographs (DoBOs 1958; GYőRI 1975) that contribute to an understanding of village norms, but also those works that specifically take into account village moral values and accepted (or sometimes enforced) behavior (RUITZ 1966; PÁPAY 1978; VERES L. 1978; NAGY 1998). Studies focusing on attitudes to work and work ethics reveal a particularly rich collection of material (FÉL - HOFER 1997).

Common to all these works is the fact that communities are interpreted as relatively closed units, in which individual opportunities and life strategies are regulated by a monolithic, unified set of values and system of norms. This model, in the aforementioned works, is a part of, and a continuation of, the research tradition (FÉL 1948), which appears in Ferdinand Tönnies's 1887 work Gemeinschaft und Gesellschaft (Community and Society) (TöNNIES 1887). The community (Gemeinschaft), which has an internal set of values and in which the collective human instinct is present and prevails in its natural, uncorrupted form, operates within a network of norms and behavioral rules. In contrast, society, the artificial community (Gesellschaft), produces an environment in which social interests and goals give rise to interpersonal relationships in an artificially regulated environment.

Works emphasizing the organic nature and closed character of village value systems and highlighting the role of upbringing (expanding Tönnies's concept), interpret the village community as a whole as a quasi-community, reinforcing the idea that village communities are in fact local groups modeled on close human relationships (such as kinship, for example), in which "natural" social "instincts" regulate interpersonal relationships (FÉL 1948). In contrast to the archipelago of these communities, society as a whole appears as an external medium. Society (i.e. larger groups that do not function as a community, according to this view) can more appropriately be described by an examination of the more instrumentalized and codified legal frameworks.

3. It is for this very reason that, beyond behavioral norms and regulative systems, local-level legal regulation plays an important role in shaping and maintaining the structure of the local public sphere. The third collection of sources for the examination of the village public sphere, therefore, focused on folk legal customs and legal practice. I also place in this group of sources those texts that examine the social manifestation at a local level of the state bureaucracy, the legal system, and the institutions associated with it - in other words, how state law and order interacts with the value system of the local community (OLÁH 2008).

There is significant literature in Hungarian dedicated to legal customs and the local legal system. The work of Ernő Tárkány Szücs, who systematically surveyed the system of folk legal customs, stands out from among them (TÁRKÁNY SzÜCs 1981). Concerning certain settlements, and with respect to source materials, comprehensive summaries are available concerning the Székely Land (IмreH 1947, 1973, 1983), Gömör (NAGY 
1998), and Sárköz in Tolna County (ZentaI 1994). This direction of research — that is, traditional codified village regulatory systems - has also attracted attention at the international level (KRAMER 1954; ISAKSSON 1967).

It is clear that the trinity of texts, norms, and legal system has exercised a mutual influence on the lives of village communities. Earlier research suggests that these were interdependent systems, where reputation, personal authority and charisma were the socially utilizable capital that had to be safeguarded. As the saying went: "Reputation costs a great deal to keep up" (VerEs P. 1978:87). It is only when a person is unable to defend their own interests verbally and by means of their behavior that the legal protection of interests arises. For a family to be involved in a lawsuit is very damaging to its prestige, almost regardless of the subject matter. There is a common saying throughout the country: "Better suffer a loss than go to court" (TÁRKÁNY SzÜCs 1981:782).

When public hearings are examined as ethnographic or anthropological sources, it is also important to bear in mind how this essentially constitutional institution fits within the framework of the public sphere that is regulated by the individual village communities. As the above train of thought suggests, the analysis of the minutes of public hearings clearly does not provide sufficient insight into the life of a particular village community. Village debates have, after all, traditionally been made public and given a legal basis only as a last resort. As we will see, the extent and effect of the inactivity that can be observed in the majority of public hearings can be explained by the functioning of contemporary rural society and the public sphere, as well as by the traditional roles that the village community reserves for the utilization of the local public sphere.

\section{PUBLIC HEARINGS AS A SPACE IN THE LOCAL PUBLIC SPHERE}

So what, in fact, is a public hearing? A public hearing is a regular and mandatory event held by the representative body of the local government. At the same time, the event is a constitutional institution that provides an opportunity for the exercise of executive power on a participatory basis. It allows room for dialogue between the elected leaders of the settlement and the local residents. It is therefore a participatory form of executive power that is aimed at creating the possibility of dialogue and facilitating the communication of diverging local interests. It is also important to point out that public hearings are a means of local control that promotes the ability to enforce interests, exert pressure, express opinions, or lodge complaints, but that cannot compel decision making (cf. Kiss 2012:15).

Public hearings suppose a social model, the basic principle of which is the maintenance of socioeconomic development and the need for closer cooperation with the population. The harmonization of the needs of the population and of diverging points of view is also important, because, in addition to formal civil society organizations (CSOs) and the selforganization of the population, local governments also have an important role to play in managing local economic and human resources. The point of public hearings is to create opportunities for direct, two-way communication, bringing about speech situations in which elected representatives and members of the public are both present. For this reason, public hearings must be held exclusively at public sessions of the representative body. The legal foundation for public hearings and the safeguarding of the local public sphere are recognized not in one individual regulation in the Municipality Law, but rather 
in several interrelated regulations that thus permeate the law as a whole: these statutory provisions can be found under different chapters and headings (Kiss 2012:24).

The task of public hearings is to present matters of public interest within the local public sphere that directly affect the lives and circumstances of village residents. Although individual problems do crop up in the minutes of public hearings (especially in very small settlements), the public hearings are essentially organized around issues of public interest: individual cases (as can be seen from the minutes) are given limited space or are not recorded. The local public sphere is thus broad but not unlimited, and its limits are legally regulated.

Issues of public interest that are raised legitimately at public hearings include those issues that concern a significant grouping within the village community. Debates, comments, and questions arise at public hearings when those in attendance consider themselves affected. Such cognitive engagement arises when an event, situation, or condition actually affects the daily lives and living conditions of the village residents (ANGelusz 1983).

Public hearings take place according to a regulated procedure, the individual treatment of which (although instructive from an anthropological point of view) lies outside the scope of the present study. There are tasks related to organization and topic selection prior to the public hearing; tasks that are accomplished in the course of the meeting (e.g. chairing the meeting, taking proper minutes); and finally, tasks that come after the public hearing (including the preparation and recording of the minutes used as source material in the present study) (KISS 2012; cf. FogARASI 2010). Each phase in the organization has a substantial influence on who is present at the event, what is said there, and what and how it is recorded. The diverging practices of each local government also have an impact on the quantity and quality of the text corpora produced, how they are made accessible, and how much publicity they are given.

Public hearings play a very important role in ensuring that certain social and development policy issues are brought to the local public debate that would not otherwise be discussed locally. Hungarian rural areas, and especially the Örség region and the Slovenian Rába region, have two significant problems to contend with - on the one hand, a lack of human resources and a stagnating or declining population; and on the other hand, the continuous and significant increase in social disparities. Rural areas made up of tiny villages are characterized not only by a relatively weak local economy but also by the absence of a local elite that would be capable of effective interest representation. Another contributing factor is the lack of any local enterprises of significant size in this region that would have at their disposal significant capacities to enforce interests. As a result, political and economic decision-making is increasingly concentrated in urban areas (SZEPESI et al. 2016). However, public hearings are not able to fulfill their intended and vital role in all respects, since there are significant limitations in terms of the local society's power to enforce its interests.

\section{THE LIMITATIONS OF PUBLIC HEARINGS}

Despite the potentially important role of the institution of the public hearing in the lives of marginal village communities, several factors limit the fulfillment of such a function. 
There are several reasons for this. The literature suggests that voters are generally not merely dissatisfied but also typically disillusioned with politics, and with local politics in particular (PÁLNÉ KovÁCs 2008). This is also illustrated by the fact that, right up to the present day, voters have failed to exploit the opportunities offered by the public hearing and have rarely participated in shaping the political direction of their settlements. However, this collective apathy is not a characteristic peculiar to the period following the change of political system, since the very same attitude was typical of the Socialist fora, and especially the village assemblies (BöHM 1987; KIss 2009). After all, the public hearing bears a strong resemblance to the village assemblies that were part of the council system under the Socialist regime. In fact, the institution of the public hearing was created in 1990 to "replace" the village assembly (KIss 2012:31).

Although local governments have other forums at their disposal for addressing the local population (local newspapers, websites, social media, etc.), none of them is fully able to fulfill the community-building function of the public hearing. As illustrated by the minutes from Vas County that I examined, such events can facilitate communication not only between the official apparatus and the voters but also among the voters themselves.

In particular, other forms of communication are unable to take over the role of public hearings because political communication very often fails to reach the local residents. There are many reasons behind the political apathy at local level. On the one hand, the programs implemented by the mayor are typically complex and difficult to follow, while cyclical programs are not transparent. The weakness of the local financial and budgetary basis is likewise problematic. In other words, the local government is typically unable to address the really important issues using its resources, thus the respective decisions are not made at local level. This means that many people do not see the importance of direct, local interest representation.

In addition, the structure of local society plays a significant role in the successful functioning of public hearings, albeit to varying degrees in each individual settlement. In settlements where the local social elite successfully manages to concentrate the resources of the local public sphere and the leadership of the settlement, a hierarchical power structure typically emerges that is not conducive to the development of open dialogue. There may be a sense that partnership is lacking, increasing factional or introspective communication within the settlement (cf. KABAI et al. 2001). Such countrywide tendencies also limit what can be achieved at local level by means of public hearings. They primarily reflect the mood of the local population, but without resulting in genuine dialogue or interest reconciliation (PÁLNÉ KovéCs 2008:119). This is due not only to a lack of trust in public and local authorities but also to the fact that authoritarianism does not foster dialogue at local level (FÁBí́n 1999).

The participatory review of local policy is cumbersome and inefficient, not just in Hungary (JÁVOR - BEKE 2012; CsANÁDI et al. 2010) but throughout Central and Eastern Europe. This, of course, also limits how members of the public enforce or present their points of view at public hearings. The first problem is that of physical participation. Public hearings, like other local government events, attract participants if the local government combines them with some kind of celebration or entertainment (KÁKAI 2004), as was the case in Kétvölgy, in the studied area, where a high turnout was ensured by combining the public hearing with the end-of-year festivities. 
Topics regularly raised in the available minutes of public hearings in several settlements include nature conservation (issues related to the work of the Örség National Park and the frequent damage caused by game animals), as well as inquiries and requests concerning local developments. Both topics are prominent in the case of research carried out to evaluate the significance of participation. Although the overall picture is relatively positive with respect to nature conservation, and the local population has managed to achieve results in certain cases (SzÁNTó 2012; KISs 2015), the same local population has proved somewhat less able to enforce its interests in the field of development policy (REISINGER 2012).

Despite their limited scope in Hungary and Central and Eastern Europe, the local population and local participation can be very effective tools in implementing certain developments. This implies a political environment in which the demand to make local voices heard comes not only "from below," but is also regarded as imperative "from above" (AKKERMAN et al. 2000). Local interests can successfully be reconciled if political and economic stakeholders and CSOs all play a role in decision-making (BLOMGREN BingHAM et al. 2005).

\section{ENVIRONMENTAL PROTECTION CHALLENGES AND PUBLIC HEARINGS}

Public hearings are limited not only because the activity and involvement of the local population are limited, but also because not all stakeholders are represented at these events in every case. The absence of bigger local enterprises, and in particular of CSOs, is striking. This results not only in the absence or inadequacy of dialogue among certain stakeholders but also in a low level of involvement on the part of certain CSOs in issues such as nature protection and environmental management.

This becomes particularly problematic when it appears impossible to communicate messages between the two parties on certain issues. The Hungarian-Slovenian border area is an excellent example of how conflicts arise from different interpretations of the role of nature conservation. One such conflict was articulated between the local councils and the CSO Védegylet [Protect the Future] in the matter of the road linking Kétvölgy with Felsőszölnök. Known by locals as the "Felsöszölnök church road," the road connects the Slovenian villages of Apátistvánfalva and Felsöszölnök, which are located in parallel valleys but not connected by a public road. A road was used earlier by the residents of Kétvölgy to walk to mass in the church in Felsöszölnök. The conflicts and lawsuits that surrounded the road, which was inaugurated on January 10, 2014, offer a perfect illustration of how Slovenian villages and environmental CSOs in Hungary view the landscape, and the role of human beings within it, in different ways (MészÁros 2015). Similar resistance, although on a smaller scale, arose in connection with the construction of the road linking Orfalu and Budinci (Büdfalva) (MészÁros 2019). Generally speaking, one of the most common causes of disagreement between the Örség National Park and residents stems from a difference in approach to landscapes and nature conservation. As in other Hungarian regions, it can be demonstrated historically how different (static and dynamic) ideas regarding the landscape in the Örség region and Vendvidék (Slovensko Porabje) have determined developments in the area (IsPÁn 2019). This is especially 
true in areas where the imposition of the Iron Curtain allowed scope for diverging attitudes towards the landscape (HARLOV-CSORTÁN 2017). Inability to reconcile interests, especially in the case of public hearings, thus not only hinders dialogue but also gives rise to conflicts and weakens the opportunities for the local involvement of CSOs.

This remains true despite the existence of examples to the contrary - albeit in an urban context. The foaming of the water in the River Rába, which prompted joint civil and local authority action against the BEGAS corporation's plans to construct a waste incinerator in Heiligenkreuz, is an instructive case study. The civil society Pro Natura St. Gotthard (PRONAS) played a prominent role in this process and sent representatives to almost every possible forum in the town. Not only did the foaming in the Rába stop as a result of this cooperation, but in 2012 the Austrian Court of Public Administration also revoked the building permits for the incinerator on formal grounds. Nature conservation represents a key development opportunity for the entire region, which not only encourages CSOs to join forces but can also make a significant contribution to the strengthening of regional identity (FEHÉRVÖLGYI 2010:136-138). In other words, the self-image of the studied area as a clean and unspoiled environment is in harmony with the direction of tourism development that defines the three national parks. However, the attitudes of local residents, CSOs, and state institutions are not always in harmony. The minutes of public hearings also reveal that there is practically no meaningful dialogue between the parties in this important area, even though the creation of services and products for ecologically conscious tourists plays a key role in the region's tourism development program (CITY OF SZENTGOTTHÁRD 2005).

The framework for the interpretation of public hearings is in part created by works on political and public administration theory, which evaluate and present this institution in terms of the efficiency and social role of public hearings. However, from an anthropological point of view, this is only one side of the coin. In terms of research and textual analysis, the interpretation of public hearings as speech events in a specific framework - where verbal expression within the community assumes a unique form - is at least of equal importance. The question remains as to the most appropriate conceptual framework for transmitting the texts recorded at public hearings for anthropological analysis. For this purpose, it seems appropriate to look at the theory of speech communities and narrative pragmatism.

\section{SPEECH COMMUNITIES}

Since, in terms of the corpus recorded in the course of the public hearing, we are not interested in the texts themselves but rather in who makes these utterances, why, and how, it is important to analyze the medium of communication and the community that produces and receives the texts during the public hearing. It is not simply that members of a village population who speak the same language produce texts using the same symbols in a way that is mutually comprehensible, creating a uniform community whose members mutually understand one another (BLOOMFIELD 1933:29), but also that the members of this community create their own internal discourses according to uniform norms and rules, creating a uniform "speech community" (LABOV 1972:120-121).

The narratives that emerge in individual village communities can be interpreted by taking into account the norms and values of the respective speech community, which 
reveal which of the texts appear valid in the villages and which can be activated. However, speech communities can be pluralistic and divided within themselves (since the positions of the different speakers within society may differ), which means that not only speech communities but also the speakers within the speech communities, can be positioned in relation to one another (MORGAN 2006:21).

The significance of this can best be grasped by considering the use of language, or speech - in this case the creation of narratives - as an activity with a social force (agency) within the life of the village community. As stated by Alessandro Duranti, participants in a speech act are mediators of this agency, regardless of their own intentions: "any act of speaking involves some kind of agency, often regardless of the speaker's intentions and the hearer's interest or collaboration. This is due to the fact that by speaking we establish a reality that has at least the potential for affecting whoever happens to be listening to us" (DURANTI 2006:451). This finding is important for the specific purposes of the present study as it defines verbal communication (including narratives) as having agency in the creation of community life, regardless of the actual intention of those participating in the communication. Thus, when endeavoring to present the linguistic strategies of a village based on the questions and answers exchanged at public hearings, it is also important to realize that verbal communication can have social agency not only by being understood as an activity (an illocutionary act), but also in terms of the opportunity and capacity for communication (DURANTI 2006:456).

When it comes to how verbal communication systems in certain villages operate as social agencies during public hearings, and the way in which they are thereby related to the issues and economic strategies of the local society, the ability to communicate and the activities of communication must therefore be taken into account simultaneously. Duranti, lacking any better term - refers to the former as ego-affirming agency (DURANTI 2006:456). In the case of public hearings, the role of this social agency can best be formulated with reference to whether or not the village community considers certain people suitable to speak and ask questions in certain situations. In other words, before examining what is said, it is important to investigate whether the community considers the individual capable of contributing as a genuine agent to the establishment and maintenance of the communication system. The evaluation of communication abilities and opportunities - and in general the right to participate in communication situations - is regulated differently by each village community. This is exemplified by the differences that can be observed in the course of public hearings. The number of participants and the number of questions, as well as their distribution, give an eloquent picture of the community.

According to Alessandro Duranti, language activities are another form of social agency. Verbal communication itself is a series of actions that bring about changes in the real world. Duranti refers to this as act-constituting agency (DuRANTI 2006:457). By definition, evaluative community speech operates as a genuine social agency, since it has a key role in decision making on community and economic issues, and, in particular, in terms of determining whose word becomes decisive in decision making, or indeed whether or not a common issue can be settled at all. However, acts of communication do not necessarily play a role in decision-making as a result of participants' rational arguments, but rather through their creation and performance of narratives. Narratives can thus be interpreted not only as the foundations of community knowledge, and perhaps 
of local identity, but also as genuine acts. These acts maintain the communication system and either strengthen or weaken the position of individual villagers. This is also true of public hearings, where often it is not arguments but entire narratives that are presented. Certain stories and narratives have considerable legitimating power in the course of public hearings.

This particular feature is relevant in the analysis of the text corpus of public hearings, as it introduces another (typically verbal) narrative knowledge system alongside the knowledge systems that are encoded in legal and administrative language. During public hearings, this is in contrast to the more abstract and (more) instrumental knowledge systems of administrative language, which exists primarily in written form. Although it is possible to view narrative-based knowledge simply as an opinion (i.e. as secondrate, easily falsifiable knowledge), such an a priori hierarchy of coexisting knowledge systems fails to take into consideration what the knowledge that is conveyed by (often contradictory) knowledge systems is used for within communities, and how. The narratives delivered in the course of public hearings, and how they are used, indicate that the understanding conveyed by narrative knowledge is not necessarily second-rate (and easily refutable) for the members of the community.

As one aspect of analysis, the distinction between narrative knowledge (or narrative paradigm) and scientific knowledge (or rational paradigm) that is commonplace today (BRUNER 1991; FISHER 1997) is a promising approach in terms of the examination of the minutes. Jean-François Lyotard, who was the first to contrast the two concepts systematically, identified the pragmatism of narrative knowledge and defined its features as follows:

1. Narratives make it possible to determine the criterion of competence in the community, thereby providing the basis for the evaluation of performances.

2. The narrative form makes possible the plurality of language games - that is, a narrative may be evaluative, denotative, or even integrative at the same time.

3. The speech act is simultaneously created not only by the narrator but also by the recipient, as well as a third person evoked and referred to by the narrator.

4. It is not only the meaning of the narrative that is important, but also the act of narration.

5. No special instruments or procedures are required to authorize the narrative (LYOTARD 1993:44-50).

The knowledge transmitted via narratives thus directly creates its own legitimacy (LYOTARD 1993:54). In other words, there is no external position from which the isolated narrator (removed from listeners and protagonists) and the subject of the narrative and its legitimacy can be validated or falsified. The legitimation of narrative knowledge is created by its continuous flow, cognition, and repetition.

Since knowledge acquired through narratives cannot be justified (or disproved) by external legitimation, the process by which narratives become everyday knowledge requires a different framework of interpretation. This process - that is, the propensity for narrative knowledge - is almost encoded within us, because employing narratives "we experience and comprehend life as a series of ongoing narratives, as conflicts, characters, beginnings, middles, and ends" (FISHER 1987:24). However, this coding has a cultural, learned character that defines the structure and types of narrative in a given community: "Narrative provides a conceptual frame that would account for the 'stories' we tell each 
other - whether such 'stories' are in the form of argumentation, narration, exposition, or aesthetic writing and performance" (FisHER 1997:313). Among the many types of narrative, the one that becomes the basis of knowledge is the one that is endowed with "good reason" to use Walter Fisher's term. These narratives, therefore, have a peculiarity that convinces listeners to listen to what is being said. What it is that convinces, of course, varies, from one context to another (CASWELL - SCHNEIDER 2003:5).

For this reason, narratives should not be expected to supply arguments that can be logically justified or falsified (BRUNER 1991). Narrative is not a succession of arguments and causal relations: "narratives are not strings of causal entailments; instead, the earlier events in a sequence of events underdetermine later events) (CAROLL 2001:26). As a result, stories alone can neither prove nor disprove anything. The person (trustworthiness) of the speaker and the proper use of the communication situation, or rather the cultural frames available to the given community, are responsible for the content of the communication - and for its acceptance as knowledge. "Narratives are cultural frames and ideologies that prefigure some stories insofar as group beliefs and values contain already articulated plots" (MAINES 1999:318). In other words, one of the most appropriate ways of publicly confronting community opinions is to present diverging opinions within narratives or within fragments of narratives. Narratives tell us a lot about the community precisely because they present the community according to culturally given structures in relation to the discussion of a concrete problem. When examining the text corpus of public hearings, it is precisely the narratives and narrative fragments that should thus play a key role.

\section{WHAT DO THE MINUTES OF PUBLIC HEARINGS TELL US?}

Since the scope of the present study does not allow for the individual presentation of the three relevant interpretative possibilities mentioned above, drawing on the examined minutes I merely present the possibilities and obstacles that textual analysis gives rise to in the course of concrete analysis. Firstly, the question of the comprehensiveness with which the spoken texts were recorded is worth examining in the course of text corpus analysis. Many of the minutes from public hearings are available only in a shortened, summarized form. This naturally also results in variance in terms of their analyzability.

In many cases, the only information we have is that "after this, the participants ${ }^{2}$ and the mayor spoke about issues other than public affairs, and past events and grievances were discussed." (ORFALU 2017). In other words, what was said at the public hearing is not quoted but merely referred to. More commonly, the person recording the text quotes the speakers at the event in indirect speech, like a narrator: "A local resident and his wife ${ }^{3}$ were the first to speak. They complained about the decision made by the Council in relation to an area with a plot number in Orfalu ${ }^{4}$. In their opinion, regardless of the fact that the site falls under Natura 2000 classification, it should have been feasible to realize the fish pond they had planned. Nevertheless, they acknowledged the decision made by

\footnotetext{
2 The participants' names are given in the minutes.

3 The speaker's name is given in the minutes.

4 The area is referred to in the minutes with its precise plot number.
} 
the Council and gave up their intention to purchase" (OrfaLu 2014). Finally, one of the least common approaches is to record direct quotes, with no external narrator reporting the dialogues in indirect speech. In this case, what was said is reproduced almost word for word:

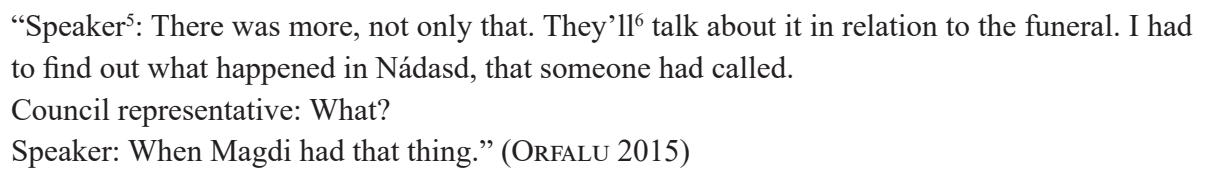

I have given these three examples one after the other as they present three diverging practices on the part of the same local government and council body. The most detailed minutes from 2015 include a written version of the dialogues as a separate supplement. There are also significant differences in terms of whether the speakers and contributors are mentioned by name in the minutes. In some settlements, both the questioners and the respondents are referred to by name, while in other villages they are mentioned merely as first, second, and third contributors.

The degree of active participation at public hearings is another difference. In Orfalu (despite the small size of the settlement), the public hearings were lengthy and full of colorful debate, while in Kétvölgy almost no questions were raised at the event held at the end of the year, despite the high turnout ensured by the end-of-year celebration. This does not necessarily mean that there is a lack of communication between the mayor and the local citizens, but rather that other forums are being used. The limitations of the village public hearings are also illustrated by the fact that there is occasionally no middle ground between the different standpoints. In other words, there is no real communication between the parties. A good example of this is the following dialogue from Orfalu:

\begin{abstract}
"Speaker:? It's pretty clear that you're not interested in the facts, because facts and answers are being given, but to no avail. The point is, as you ${ }^{8}$ yourself said, to find out whether any corruption took place, and whether there is any fraud or favoritism.

Respondent: There's no doubt about it.

Speaker: Don't make insinuations... . ${ }^{9}$ it's nothing more than slander for the time being. So it seems we're not going to get any questions and answers here. Not a chance. If we could, we'd be able to find something out and get along fine with each other, cooperating sensibly. This is a nice place, we don't need any kind of mudslinging, insinuations, or spitefulness"' (Orfalu 2015).
\end{abstract}

One common problem is the small number of people present at the event, as not everyone receives the invitation:

\footnotetext{
5 In the record of the dialogue in the minutes, all the speakers and respondents are referred to by name.

6 The name of the speaker is given in the minutes.

7 The names of the participants are given in the minutes.

8 The contributor is mentioned by name.

9 Part omitted from the minutes.
} 


\begin{abstract}
"Speaker: ${ }^{10}$ It's been explained that the reason there aren't many people at the public hearing is because the invitations were only posted in a few places, unlike the Christmas program invitations, which were sent to every household.

Respondent: Eight or ten years ago, all the meetings were advertised. We can learn from this for the future." (KONDORFA 2016)
\end{abstract}

In addition to the limitations mentioned above, the analysis of the texts themselves is made even more difficult by the fact that in many cases what is said is in a deictic relationship with an event that took place earlier, or with a piece of information that is not mentioned, which cannot be found out based on the respective minutes: "It's impossible to put up with what's happening in this village. There's nowhere to go, either. You'll not even be able to leave the house soon. We all know what I'm talking about." (Orfalu 2015). In other cases, however, events are recalled and narratives and stories are told that the participants in the event remember in different ways:

\begin{abstract}
"when I first started doing medicinal plant walks, you guys put on an event and I went to you and told you that from now on we were having a beekeeping demonstration every weekend, and it got them crazy and they said, 'This is our event.' Then I said, 'Well, you have to understand, in that case, I could even start our event from the folk museum on the bank of the Rába" (ORFALU 2015).
\end{abstract}

Conflicting, incongruent narratives and memories illustrate the resurfacing of local narrative knowledge, the validity, and power of which can only be properly contextualized employing ethnographic fieldwork.

Despite all these limitations, the examination of the minutes revealed certain types of problems that stir up local public opinion, spurring people on to active participation. The most important of these are relationships with the environment and the role of nature conservation. Questions on these topics are regularly raised at public hearings. At the public hearing in Apátistvánfalva held on December 15, 2019, for example, most of the questions concerned this problem:

"Second speaker: There are so many game animals that they got into my fenced garden right
next to my house and gnawed at everything, from the rose bushes to the pine trees. That's a
lot of damage for me. There's a small forest not far from us that was cultivated land a while
back but is now pretty much forested. Part of this forest is council property. Could this area be
thinned out? I realize there's no capacity and no labor force, but the locals ought to be permitted
to clear the area, then maybe the wild animals wouldn't get in.
Third speaker: Don't just feed them and keep them to hunt: game animals need to be kept away
from residential areas. Notify owners of the date of the hunt, don't just put up a sign. I've said
many times that there need to be notices in other places, not just at the bus stop: not everyone
sees it there.
Fourth speaker: The funeral parlor needs a cloakroom and a toilet: people who've come a long
way to attend a funeral are complaining that there isn't one. I live in the middle of the village:

10 The names of the participants are given in the minutes.

11 The participants' names are given in the minutes. 
the deer are eating the ivy off the wall even though there's a dog; they even attack the dog. Fifth speaker: Mowing large areas of grass is a problem, I can't do it by myself. Everyone wants it mowed but they don't have anyone to do it, so it'd be nice to have a list in the spring of who needs mowing done. Beauty is one of our village's greatest assets.

Sixth speaker: The Greens shouldn't interfere with the mowing.

Seventh speaker: We need stream regulation, mowing should take place there as well. The cedar trees should be cut back nicely in the cemetery. I would like to thank the outgoing council for its work and wish the new members strength and health to continue it. Thank you very much for the Christmas gift.

Eighth speaker: The banks of the stream should be mowed by hand.” (APÁTISTVÁNFALVA 2019)

These and similar questions arise year after year: "wild boars are rooting up the fields and meadows, which then have to be set to rights and mowed by the owners. This is a big burden for older people." (APÁTISTVÁNFALVA 2017). Or earlier: "Second speaker: If the wild boars do cause damage, where should it be reported, and to whom?" (ApÁTISTVÁNFALVA 2015). Occasionally, the Örség National Park is referred to as the main obstacle to environmental conservation and management: "the speaker pointed out that it is not possible to mow a stretch of 60 meters on their land as they had received a document from the Örség National Park stating that that particular area was strictly protected and that mowing was not permitted there" (ORFALU 2015/2). On other occasions, reference is made to the responsibility of the hunting association:

\footnotetext{
"Speaker: ${ }^{12}$ points out that for years they have had a problem with the respective hunting association in connection with the payment of compensation for damage done by game animals. Promises have been made on several occasions that the area affected by wild boar would be inspected in the presence of both parties, who would come to an agreement on the amount of damage incurred, but the representatives of the association have failed to turn up at the agreed time. The individual would like to raise this issue with the hunting associations operating in the settlement" (APÁTISTVÁNFALVA 2014).
}

\section{SUMMARY}

This study aimed to demonstrate the usefulness and the lessons that can be learned from a type of source that has not been sufficiently analyzed to date. Data from 29 sets of minutes from four neighboring small settlements suggest that the use and inclusion in research of the text corpus that comprises the large available quantities of such sources can effectively supplement, although not replace, ethnographic fieldwork based on participant observation. At the same time, the examination of the text corpus, along with other internal sources related to the local public sphere, also makes it possible to create an image of the internal life of an individual settlement and the dynamics of its power relations that would not otherwise be available for research.

12 The full name and address are given in the minutes. 
An additional task is to analyze the use of social media and the respective text corpus in individual settlements, since in some settlements the prominent social media presence of the mayor or the local council takes over the role of the public hearing to a greater or less extent. An analysis of the activities of the Facebook groups in each village can likewise be instructive.

Particularly during the pandemic, Hungarian ethnographic research must take advantage of opportunities to access relevant ethnographic data without being present in the field in person. The precise methodology and opportunities for this can be explored only with respect to a far larger text corpus, as already clear from this collection of data. This is work that will need to be done in the coming years.

\section{REFERENCES CITED}

AKKerman, Tjitske - HAJER, Maarten - Grin, John 2000 The Interactive State: Democratisation from Above? Political Studies 52:82-95. ANGelusz, Róbert

1983 Kommunikáló társadalom [Communicating Society]. Budapest: Gondolat. BaLÁzs, Géza - TaKács, Szilvia

2009 Bevezetés az antropológiai nyelvészetbe [An Introduction to Anthropological Linguistics]. Budapest - Celldömölk: Pauz-Westermann - Inter - PRAE.HU.

BATÁR, Levente

2007 A beszólás mint beszédaktus [Disrespectful Comments as Speech Acts]. Magyar Nyelvör 131(4):451-464.

Blomgren Bingham, Lisa - Nabatchi, Tina - O'Leary, Rosemary

2005 The New Governance: Practices and Processes for Stakeholder and Citizen Participation in the Work of Government. Public Administration Review 65(5):547-558.

BLOOMFIELD, Leonard

1933 Language. New York: Holt, Rinehart \& Winston.

BőHM, Antal

1987 A helyi hatalom müködése. [The Functining of Local Power]. Budapest: MSZMP KB Társadalomtudományi Intézete.

BRUNER, Jerome $\mathrm{S}$.

1991 The Narrative Construction of Reality. Critical Inquiry 18:1-21.

CAROLl, Noël

2001 On the Narrative Connection. In van Peer, Willie - Chatman, Seymour (eds.) New Perspectives on Narrative Perspective, 118-133. New York: SUNY Press.

CASWEll, Daryll - SCHNeIDER, Barbara

2003 Building Community and Creating Knowledge in the Interdisciplinary Classroom. History of Intellectual Culture 3. e-journal: http://www.ucalgary. $\mathrm{ca} / \mathrm{hic}$ (accessed November 8, 2020)

Doвos, Ilona S.

1958 Szegényember vízzel föz. Életrajzi vallomások [Poor Man Cooks With Water. Biographical Confessions]. Budapest: Magvetö. 
DuRANTi, Alessandro

2006 Agency in Language. In DurAnti, Alessandro (ed.) A Companion to Linguistic Anthropology, 451-473. Oxford: Blackwell.

FÁBIÁN, Zoltán

1999 Tekintélyelvüség és elöitéletek [Authoritarianism and Prejudice]. Budapest: Új Mandátum.

FEHÉRVÖLGYI, Beáta

2010 Határtalan lehetőségek a határ mentén [Boundless Possibilities in a Border Region]. Doctoral Thesis. Veszprém: Pannon University, Doctoral School of Management Sciences and Business Administration. http://konyvtar.unipannon.hu/ doktori/2010/Fehervolgyi_Beata_dissertation.pdf (acessed April 12, 2020)

FÉL, Edit

1948 A magyar népi társadalom életének kutatása [Research on Life in Hungarian Folk Society]. Budapest: Kelet-Európai Tudományos Intézet.

FÉL, Edit - HofER, Tamás

1997 Arányok és mértékek a paraszti gazdálkodásban [Proportions and Measures in Peasant Farming]. Budapest: Balassi.

FisHeR, Walter R.

1987 Human Communication as Narration: Towards a Philosophy of Reason, Value, and Action. Columbia: University of South Carolina Press.

Fogarasi, József

2010 A helyi önkormányzat képviselő-testülete, közgyülése [The Local Government Representative Body and Its General Meeting]. In Fogarasi, József (ed.) $A$ helyi önkormányzatok, 207-295. Budapest: HVG ORAC.

Gulya, János

1978 Az etnolingvisztika magyar „előfutárai” [Hungarian "Forerunners” of Ethnolinguistics]. In SzATHMÁRI, István (ed.) Tanulmányok a magyar és finnugor nyelvtudomány történetéböl (1850-1920), 131-135. Budapest: Tankönyvkiadó.

GYŐRI, Klára

1975 Kiszáradt az én örömem zöld fája. (Emlékezés) [The Green Tree of My Joy Has Withered. (A Memoir)]. Bucharest: Kriterion.

Harlov-CSOrtán, Melinda

2017 From the Borderland of the Iron Curtain to European and World Cultural Heritage. Folklore 70:193-224.

HoppáL, Mihály

1970 Egy falu kommunikációs rendszere [The Communication System of a Village]. IMREH, István

Budapest: MRT Tömegkommunikációs Kutatóközpont.

1947 Székely falutörvények [Szekler village laws]. Cluj-Napoca (Kolozsvár): Erdélyi Tudományos Intézet.

1973 A rendtartó székely falu [The Orderly Szekler Village]. Bucharest: Kriterion. 
1983 A törvényhozó székely falu. I. A székely falutörvények világa. II. Székely falutörvények, rendtartások [The Legislative Szekler Village. I. The World of Szekler Village Laws. II. Szekler Village Laws and Regulations]. Bucharest: Kriterion.

ISAKSSON, Olof

1967 Bystámma och bystadga. Organisationsformer $i$ övre Norrlands kustbyar Skytteanska samfundets handlingar 5. [Village Folk and Village Charters. Organizational Forms of the Upper Norrland Coastal Villages]. Uppsala: IsPÁN, Ágota Almqvist \& Wiksell Boktryteri.

2019 Transformation of a Strictly Controlled Border Area into a Tourist Destination Making Heritage in Communist Hungary. Traditiones 48(1):77-100.

JÁvor, Benedek - BEKE, Zsolt Frigyes

2013 Résztvevők és apatikusok. Adalékok a társadalmi részvétel helyzetéhez Magyarországon [The involved and the apathetic. Contributions to the condition of social participation in Hungary]. Politikatudományi Szemle 22(4):59-89.

Kabai, Imre - Marelyin, Kiss József - DÉnes, Attila

2001 A helyi nyilvánosság és a helyi médiumok [The Local Public Sphere and the Local Media]. Jel-Kép 2:9-24.

KÁKAI, László

2004 Önkormányzunk értetek, de nélkületek! [We'll Self-Govern for You, but without You!]. Budapest: Századvég.

Keszeg, Vilmos

2002 Az írás és a beszéd konfliktusa: egy írástudó asszony „pere” [The Conflict between Writing and Speech: The "Trial" of a Literate Woman]. In KESZEG, Vilmos (ed.) Homo narrans. Emberek, történetek és kontextusok, 147-178. Cluj-Napoca (Kolozsvár): KOMP-PRESS - Korunk Baráti Társaság.

2011 A történetmondás antropológiája. Egyetemi jegyzet [The Anthropology of Storytelling. University Lecture Notes]. Cluj-Napoca (Kolozsvár): Kriza János Néprajzi Társaság - BBTE Magyar Néprajz és Antropológia Tanszék. (Néprajzi Egyetemi Jegyzetek, 5.)

2012 Történetek és történetmondás Detrehemtelepen [Stories and Storytelling in Detrehemtelep]. Cluj-Napoca (Kolozsvár): Erdélyi Múzeum-Egyesület. (Emberek és kontextusok, 6.)

KIss, Gabriella

2015 Társadalmi részvételi folyamatok értékelése környezeti ügyekben. A népszavazás és a közmeghallgatás értékelése hulladékos ügyekben a résztvevök szemszögéböl [The Evaluation of Social Participation Processes in Environmental Issues. An Evaluation of the Referendum and the Public Hearing in Waste-Related Affairs from the Participants' Perspective]. Budapest Corvinus University. Doctoral (PhD) dissertation. http://phd.lib.uni-corvinus. $\mathrm{hu} / 834 /$ (accessed December 13, 2020)

KIss, Mónika Dorota

2009 A falugyülés hatásköre a községekben [The Authority of the Village Assembly in Communities]. Jura 15(1):54-70. 
2012 A közmeghallgatás helyi önkormányzati jogintézménye. Doktori értekezés [The Legal Institution of the Public Hearing in Local Government. A doctoral dissertation.] Doctoral School of the Faculty of Law of the University of Pécs. http://real.mtak.hu/3890/1/\%C3\%89rtekez\%C3\%A9s.pdf (accessed December 20, 2020)

Kotics, Jószef

1993 Csendháborítás vagy a közösség bosszúja? A charivari szokása Rozsnyó kézmúves közösségében a 19. században [Breach of Silence or Community Vengeance? The Custom of Charivari in the Handicraft Community of Rozsnyó in the $19^{\text {th }}$ Century]. Néprajzi Látóhatár 2(1-2):153-160.

2001 Mások tekintetében [In the Eyes of Others]. Miskolc: University of Miskolc. Kramer, Karl-Sigismund

1954 Die Nachbarschaft als bäuerliche Gemeinschaft Verlag Bayerische Heimatforschung. München: Pasing.

LYOTARD, Jean-François

1993 A posztmodern állapot [The postmodern Condition]. In BuJALOS, István (ed.) A posztmodern állapot, 7-146. Budapest: Századvég.

MAINES, David

1999 Information Pools and Racialized Narrative Structures. Sociological Quarterly 40:317-326.

MÁRKUS, István

1979 Nagykörös. Budapest: Szépirodalmi.

MÉszÁros, Csaba

2015 A kvalitatív kutatás esélyei a magyar-osztrák-szlovén hármas határ térségében [Prospects for Qualitative Research in the Hungarian-Austrian-Slovenian Triple Border Area]. In TuRAI, Tünde (ed.) Hármas határok néprajzi értelmezésben / An Ethnographic Interpretation of Tri-Border Areas, 73-84. Budapest: MTA BTK Néprajztudományi Intézet.

Morgan, Marcyliena

2006 Speech Community. In Duranti, Alessandro (ed.) Companion to Linguistic Anthropology, 3-22. Oxford: Blackwell.

NAGY, Janka Teodóra

1998 Jogi néphagyományok két gömöri faluban [Legal Folk Traditions in two Gömör Villages]. Debrecen: Kossuth Lajos University. (Gömör Néprajza 51.)

OLÁH, Sándor

2008 Kivizsgálás. Írások az állam és a társadalom viszonyáról a Székelyföldön 1940-1989 [Inquiry. Writings on the Relationship between State and Society in the Székely Land, 1940-1989]. Csíkszereda: Pro-Print Könyvkiadó.

PÁLnÉ KovÁcs, Ilona

2008 Helyi kormányzás Magyarországon [Local Governance in Hungary]. Budapest - Pécs: Dialóg Campus.

PÁPAY, Zsuzsa

1989 Rang, párválasztás, közvélemény. Jelentés egy Mátra-vidéki faluból [Rank, Partner Selection, Public Opinion. Report from a Village in the Mátra]. Budapest: Gondolat. 
ReISINGER, Adrienn

2012 A társadalmi részvétel a helyi fejlesztési politikában Magyarországon - fókuszban a civil/nonprofit szervezetek [Social Participation in Local Development Policy in Hungary - CSOs/Non-Profit Organizations in Focus]. Civil Szemle 30(1):23-44.

RuITz, Izabella

1966 A parasztifjúság társasélete a Bódva vidékén (1880-1950) (2. rész) [The Social Life of Peasant Youth in the Bódva Region (1880-1950) (Part 2)]. Ethnographia 77(1):93-117.

SzÁNTó, Richárd

2012 Társadalmi részvétel Magyarországon. Siker vagy kudarc? [Social Participation in Hungary. Success or Failure?]. Kovász 16(1-4):33-53.

SzENDREY, Ákos

1937 A társadalmi érintkezés formái [Forms of Social Interaction]. Ethnographia 48(4):372-385.

SZENTGOTTHÁRD VÁROS

2005 Szentgotthárd város idegenforgalmi fejlesztési koncepciója és stratégiai programja [Tourism Development Concepts and Strategic Program in the Town of Szentgotthárd]. http://nagyrakos.hu/szentgotthard/download. ashx?type $=$ file \&id=381 (accessed on October 26, 2015)

SzEPEsi, Balázs - BaJnay, Zsófia - FAZEKAs, Gergely - KIss, Fanni - Kovács, András

2016 A magyar vidék helyzete [The Situation in Rural Hungary]. Budapest: HÉTFA Kutatóintézet.

TÁRKÁNY SZÜCS, Ernő

1981 Magyar jogi népszokások [Hungarian Legal Folk Customs]. Budapest: Gondolat.

TöNNIES, Ferdinand

1891 Gemeinschaft und Gesellschaft Grundbegriffe der reinen Soziologie. Leipzig: Fues's Verlag.

VARGYAS, Gábor

2006 „Lefelé jártak?” Kapcsolattartó beszédaktusok Lészpeden. A moldvai csángók „,beszédnéprajzához" ["Have you been down that way?” Speech Acts for Keeping in Touch in Leszpéd. The "Speech Folklore" of the Moldavian Csangos]. In EkLER, Andrea - Mikos, Éva - VARgyas, Gábor (eds.) Teremtés. Szövegfolklorisztikai tanulmányok Nagy Ilona tiszteletére, 326-353. Budapest: L'Harmattan.

VEREBÉLYI, Kincső

2005 A beszéd mint szokás [Speech as Custom]. In VerebÉLYi, Kincső (ed.) Minden napok, jeles napok. Hétköznapok és ünnepek a népszokások tükrében, 60-72. Budapest: Timp.

VERES, László

1978 A paraszti értékrend szabályai Mátraderecskén [The Rules of the Peasant Value System in Mátraderecske]. In BAKó, Ferenc (ed.) Mátraderecske. Néprajzi tanulmányok, 119-130. Eger. (Tematikus és lokális monográfiák 3.) 
VERES, Péter

1978 A Balogh család története [The History of the Balogh Family]. Budapest: Magvetö - Szépirodalmi.

ZENTAI, Tünde

1994 Öcsény régi faluszervezete [Old Village Organization in Öcsény]. Öcsény: Representative body of the Ö́csény local council.

\section{MINUTES USED}

1. Minutes of the public session of the Representative Body of the Apátistvánfalva Local Government and public hearing held on December 22, 2013.

2. Minutes of the public session of the Representative Body of the Apátistvánfalva Local Government and public hearing held on December 21, 2014, starting at 10 a.m.

3. Minutes of the public session of the Representative Body of the Apátistvánfalva Local Government held on December 20, 2015, at 9 a.m.

4. Minutes of the public hearing of the Representative Body of the Apátistvánfalva Local Government held on December 11, 2016 at 10.30 a.m.

5. Minutes of the public hearing of the Representative Body of the Apátistvánfalva Local Government held on December 17, 2017 at 9.32 a.m.

6. Minutes of the public hearing of the Representative Body of the Apátistvánfalva Local Government held on December 15, 2019, at 10.00 a.m.

7. Minutes of the public hearing of the Representative Body of the Kétvölgy Local Government held on December 21, 2014.

8. Minutes of the public hearing of the Representative Body of the Kétvölgy Local Government held on December 20, 2015.

9. Minutes of the public hearing of the Representative Body of the Kétvölgy Local Government held on December 18, 2016.

10. Minutes of the public hearing of the Representative Body of the Kétvölgy Local Government held on December 17, 2017.

11. Minutes of the public hearing of the Representative Body of the Kétvölgy Local Government held on December 16, 2018.

12. Minutes of the public hearing of the Representative Body of the Kétvölgy Local Government held on December 22, 2019.

13. Minutes of the public hearing of the Representative Body of the Kondorfa Local Government held on December 22, 2012 at 4 p.m.

14. Minutes of the public hearing of the Representative Body of the Kondorfa Local Government held on December 16, 2013 at 5 p.m.

15. Minutes of the public hearing of the Representative Body of the Kondorfa Local Government held on December 22, 2014 at 5 p.m.

16. Minutes of the public hearing of the Representative Body of the Kondorfa Local Government held on December 19, 2016 at 5 p.m.

17. Minutes of the public hearing of the Representative Body of the Kondorfa Local Government held on December 22, 2017 at 2.30 p.m.

18. Minutes of the public hearing of the Representative Body of the Kondorfa Local Government held on December 12, 2018 at 4 p.m. 
19. Minutes of the public hearing of the Representative Body of the Kondorfa Local Government held on December 21, 2019 at 6 p.m.

20. Minutes of the public forum and public hearing of the Representative Body of the Orfalu Local Government held on November 28, 2014.

21. Minutes of the public forum and public hearing of the Representative Body of the Orfalu Local Government held on April 28, 2015.

22. Minutes of the public session of the Representative Body of the Orfalu Local Government held on May 6, 2015.

23. Minutes of the public session of the Representative Body of the Orfalu Local Government held on July 27, 2015.

24. Minutes of the public forum and public hearing of the Representative Body of the Orfalu Local Government held on November 11, 2016.

25. Minutes of the public forum and public hearing of the Representative Body of the Orfalu Local Government held on November 22, 2017.

26. Minutes of the combined public hearing and session of the Representative Body of the Orfalu Local Government held on December 18, 2018.

27. Minutes of the combined public hearing and session of the Representative Body of the Orfalu Local Government held on November 21, 2019

28. Minutes of the combined public hearing and session of the Representative Body of the Orfalu Local Government held on October 6, 2020.

Csaba Mészáros is a senior research fellow at the Institute of Ethnology of the Research Centre for the Humanities. He is a member of the Department of Social Anthropology and has been involved in a number of Hungarian and international research projects in Siberia and the Carpathian Basin. His interests cover a wide range of topics, from ecological anthropology to kinship studies. The present paper is the outcome of his current research project on village communities at the Hungarian-Slovenian border, financed by the National Research, Development and Innovation Office (project number SNN 126 230). E-mail: meszaros.csaba@btk.mta.hu

Open Access. This is an open-access article distributed under the terms of the Creative Commons Attribution 4.0 International License (https://creativecommons.org/licenses/by/4.0), which permits unrestricted use, distribution, and reproduction in any medium, provided the original author and source are credited, a link to the CC License is provided, and changes - if any - are indicated. (SID_1) 